\title{
KAJIAN KARAKTERISTIK SENSORIS DAN KIMIA BUBUR INSTAN BERBASIS TEPUNG MILLET PUTIH (Panicum miliceum L.) DAN TEPUNG KACANG MERAH (Phaseolus vulgaris $L$.)
}

\author{
SENSORY EVALUATION AND CHEMICAL CHARACTERISTICS OF INSTANT \\ PORRIDGE MADE FROM WHITE MILLET FLOUR AND RED BEANS FLOUR
}

\author{
R. Baskara Katri Ananditoo ${ }^{1)}$, Siswanti ${ }^{1)}$, dan Dewi Tri Kusumo ${ }^{2)}$ \\ ${ }^{1)}$ Program Studi Ilmu dan Teknologi Pangan, Fakultas Pertanian, Universitas Sebelas Maret \\ 2) Alumni Program Studi Ilmu dan Teknologi Pangan, Universitas Sebelas Maret \\ email: anandito_ito@yahoo.com
}

\begin{abstract}
The objectives of this study were to determine the best formula of instant porridge made from white millet (Panicium milaceum L) flour and red beans (Phaseolus vulgaris L.) flour based on sensory evaluation and to determine chemical properties of selected instant porridge formula. The ingredients of instant porridge were white millet flour, red beans flour, milk powder, sugar, and salt. The selected formula was obtained from formulation with the best consumer acceptance. The result showed that selected formula was $39.59 \%$ white millet flour, 31.25 $\%$ red bean flour, $17.71 \%$ milk powder, $10.41 \%$ sugar, and 1,04\% salt. The chemical compositions of selected formula were $5.46 \%$ moisture content, $4.12 \%$ ash, $5.42 \%$ fat, $10.73 \%$ protein, and $74.27 \%$ carbohydrate. Total calori of selected formula was $205.38 \mathrm{kkal}$.
\end{abstract}

Keywords: instant porridge, white millet flour, red bean flour, sensory evaluation, chemical composition

\begin{abstract}
ABSTRAK
Tujuan penelitian ini adalah menentukan formula bubur instan berbasis tepung millet putih dan tepung kacang merah berdasarkan sifat sensoris dan menentukan sifat kimia bubur instan formula terpilih. Bubur instan dibuat dari tepung millet putih (Panicium milaceum L), tepung kacang merah (Phaseolus vulgaris L.), susu bubuk, gula, dan garam. Pemilihan formula terpilih berdasarkan sifat sensoris terhadap lima atribut mutu, yaitu warna, aroma, rasa, tekstur, dan keseluruhan. Selanjutnya, dilakukan analisa proksimat dan nilai kalori pada bubur instan formula terpilih. Hasil penelitian menunjukkan bahwa formula terpilih bubur instan berdasarkan sifat sensoris adalah $39.59 \%$ tepung millet putih, $31.25 \%$ tepung kacang merah, $17.71 \%$ susu bubuk, $10.41 \%$ gula halus, dan $1.04 \%$ garam. Sedangkan komposisi kimia bubur instan formula terpilih kadar air $5.46 \%$, kadar abu 4,12 \%, kadar lemak 5,42 \%, kadar protein $10.73 \%$, dan kadar karbohidrat $74.27 \%$. Nilai kalori setiap 48 gram adalah 205.38 kkal.
\end{abstract}

Kata Kunci : bubur instan, tepung millet putih, tepung kacang merah, sifat sensoris, komposisi kimia

\section{PENDAHULUAN}

Indonesia termasuk salah satu negara tropis dengan keanekaragaman yang melimpah, salah satunya adalah keanekaragaman dalam hal jenis tanaman pangan. Beberapa jenis tanaman pangan lokal seperti serealia, umbi-umbian dan kacangkacangan dapat tumbuh subur hampir di seluruh wilayah Indonesia. Menurut Almatsier (2001) diversifikasi pangan merupakan upaya untuk menganekaragamkan pola konsumsi pangan masyarakat dalam rangka meningkatkan mutu gizi makanan yang dikonsumsi yang pada akhirnya akan meningkatkan status gizi penduduk dan menghindari ketergantungan pada satu jenis makanan tertentu. Salah satu produk olahan pangan yang dapat dikembangkan adalah bubur instan. Bubur merupakan makanan dengan tekstur lunak sehingga mudah untuk dicerna yang termasuk makanan cepat saji sehingga mudah dikonsumsi. Penyajian bubur instan adalah dengan menambahkan air panas sehingga mudah larut.

Millet putih (Panicium milaceum L) merupakan salah satu komoditas lokal yang memiliki potensi untuk dimanfaatkan sebagai bahan baku bubur instan. Penelitian tentang pemanfaatan millet sebagai pangan sudah 
banyak dilakukan. Rachmawanti, dkk (2010), telah melakukan penelitian tentang pemanfaatan millet kuning sebagai substitusi tepung terigu dalam pembuatan mi kering. Millet kuning juga dapat digunakan sebagai bahan dasar pembuatan makanan pendamping ASI (Anandito, dkk., 2010; Pramesta, dkk., 2012; Husna, dkk., 2012; Arifianti, dkk., 2012; dan Ardhiandito, dkk., 2013). Millet putih merupakan salah satu bahan pangan sumber karbohidrat. Menurut Faesal (2013) kandungan nutrisi dari millet putih (proso millet) adalah kadar karbohidrat $80.4 \%$; kadar protein $12.3 \%$; kadar lemak $1.7 \%$ dan serat kasar $0.9 \%$.

Untuk meningkatkan kadar protein bubur instan, maka diperlukan bahan lain, yaitu kacang merah. Kacang merah (Phaseolus vulgaris L.) merupakan salah satu jenis kacang-kacangan yang potensial dan mudah didapat di Indonesia. Tepung kacang merah memiliki kandungan protein tinggi, dapat diminimalkan kandungan zat anti gizinya melalui proses perendaman dan pemasakan (Shimelis \& Rakshit, 2006). Kacang merah memiliki komposisi kimia per $100 \mathrm{~g}$ sebagai berikut kalori $331 \mathrm{kkal}$, protein 25 gr, lemak 1 gr, karbohidrat 58 gr, dan air 14 gr (Arinanti, 2005). Penelitian yang dilakukan oleh Marsono et al. (2003) menunjukkan bahwa kacang merah juga bermanfaat untuk menurunkan kadar gula dalam darah daripada kacang lain seperti kacang kedelai, kapri, gude, umbi-umbian, dan juga pisang. Ini disebabkan karena kacang merah memiliki indeks glikemik (IG) 26. Sedangkan IG pada nasi adalah 80, singkong 78, sukun 90, kimpul 95, kacang kedelai 31, dan kacang kapri IG-nya 30. Makanan yang mempunyai nilai IG rendah akan lebih menguntungkan dalam pengendalian gula darah dibandingkan makanan yang mempunyai IG tinggi.

Tujuan dari penelitian ini adalah memperoleh formula bubur instan berbasis tepung millet putih dan kacang merah terbaik berdasarkan sifat sensoris dan menentukan sifat kimia bubur instan formula terpilih.

\section{METODE PENELITIAN}

\section{Bahan}

Pada penelitian ini, bahan utama yang digunakan adalah millet putih (Panicum miliceum L.) dan kacang merah (Phaseolus vulgaris $L$.) yang semuanya diperoleh dari Pasar Legi, di daerah Surakarta. Selain bahan utama, untuk pembuatan bubur instan dibutuhkan pula bahan lainnya, yaitu susu bubuk full cream, garam, dan gula halus, yang diperoleh dari minimarket di daerah Surakarta. Diperlukan juga bubur komersial yaitu "Super Bubur" sebagai pembanding, yang diperoleh dari minimarket di daerah Surakarta.

\section{Alat}

Peralatan yang digunakan dalam penelitian ini adalah alat-alat pembuat tepung millet putih yaitu blender, ayakan 80 mesh, baskom, dan alat penampi. Alat yang digunakan untuk pembuatan tepung kacang merah pratanak adalah baskom, cabinet dryer, autoklaf, penepung, dan ayakan 50 mesh. Pembuatan bubur instan menggunakan baskom, drum dryer, alat penepung, dan ayakan 60 mesh. Selain itu, digunakan alat untuk analisis proksimat. Untuk penentuan total kalori digunakan bomb calorimeter.

\section{Tahapan Penelitian}

\section{Pembuatan Tepung Millet Putih}

Millet putih dihilangkan kulit arinya kemudian dilakukan pengecilan ukuran terhadap endospermnya. Setelah itu, dilakukan pengayakan 80 mesh sehingga didapatkan tepung millet putih.

\section{Pembuatan Tepung Kacang Merah Pratanak}

Kacang merah direndam dalam larutan natrium bikarbonat 4,2\% selama 4 jam dengan perbandingan 1:3. Fungsi dari perendaman dengan natrium bikarbonat untuk melunakkan tekstur, mengurangi komponen antinutrisi (Rehman et al., 2000). Setelah direndam, kacang merah ditiriskan dan dicuci dengan aquades. Kemudian dilakukan pemanasan dengan autoclave pada suhu 
$121^{\circ} \mathrm{C}$ selama 2 menit. Fungsi dari pemanasan dengan autoclave adalah untuk mematangkan kacang merah sehingga teksturnya menjadi lunak. Kemudian kacang merah dikeringkan pada cabinet dryer selama 18 jam. Kacang merah kering kemudian ditepungkan dengan mesin penepung, selanjutnya tepung kacang merah diayak dengan ayakan 50 mesh.

\section{Penentuan Formula Awal Bubur Instan}

Bahan-bahan yang digunakan dalam pembuatan bubur instan ini adalah tepung millet putih sebagai sumber karbohidrat, tepung kacang merah pratanak sebagai sumber protein, susu sebagai sumber protein dan lemak serta gula dan garam untuk menambah cita rasa. Penentuan formula awal produk ini berdasarkan trial dengan beberapa formula yang berbeda kemudian dipilih formula dengan rasa yang terbaik. Dari formula awal tersebut kemudian dilakukan variasi terhadap jumlah bahan baku yang dipakai. Formula bubur instan yang dihasilkan adalah formula 1 (F1) 39,59\% tepung millet putih; $31.25 \%$ tepung kacang merah pratanak; $17.71 \%$ susu bubuk full cream; $10.41 \%$ gula halus; dan $1.04 \%$ garam. Formula 2 (F2) $35.42 \%$ tepung millet putih; $35.42 \%$ tepung kacang merah pratanak; $17.71 \%$ susu bubuk full cream; $10.41 \%$ gula halus; dan $1.04 \%$ garam. Formula 3 (F3) 31,25\% tepung millet putih; $39,59 \%$ tepung kacang merah pratanak; $17.71 \%$ susu bubuk full cream; $10.41 \%$ gula halus; dan $1.04 \%$ garam.

\section{Pembuatan Bubur Instan}

Pembuatan bubur instan dilakukan berdasar metode yang dilakukan oleh Slamet (2011). Bahan yang digunakan dalam pembuatan bubur instan yaitu tepung millet putih, tepung kacang merah pratanak, susu bubuk, gula dan garam dicampur, kemudian ditambah air dengan perbandingan air : campuran bahan adalah 5:1. Kemudian campuran tersebut dimasak hingga tergelatinisasi sehingga diperoleh slurry. Slurry tersebut kemudian dikeringkan dengan drum dryer dengan suhu $140{ }^{\circ} \mathrm{C}$. Hasil dari pengeringan adalah berupa flake tepung campuran. Flake tersebut selanjutnya dikecilkan ukurannya dan diayak dengan ukuran saringan 60 mesh sehingga dihasilkan tepung bubur instan.

\section{Pengujian Sifat Sensoris Bubur Instan}

Ketiga formula bubur instan selanjutnya diuji sifat sensorisnya untuk mengetahui tingkat penerimaan konsumen terhadap produk sehingga didapatkan formula terpilih. Uji sensoris dilakukan dengan uji kesukaan metode scoring (Setyaningsih dkk, 2010) yang dilakukan oleh 30 orang panelis tidak terlatih. Penyajian bubur instan dilakukan dengan cara menambahkan air panas $\left( \pm 80^{\circ} \mathrm{C}\right)$ pada tepung bubur instan dengan perbandingan tepung bubur instan:air adalah 1:4 sambil diaduk sampai terbentuk tekstur yang kental. Uji sifat sensoris yang dilakukan meliputi lima parameter yaitu warna, aroma, rasa, tekstur dan overall.

\section{Analisis Kimia Bubur Instan}

Bubur instan formula terpilih berdasarkan sifat sensoris selanjutnya dianalisis secara kimia untuk mengetahui nilai gizinya. Komponen yang diuji adalah kadar air, kadar lemak, kadar protein, kadar abu, dan kadar air by different (AOAC, 1995). Sedangkan analisa total kalori menggunakan Bomb Calorimeter (Mulyaningsih dan Rosida, 2002).

\section{HASIL DAN PEMBAHASAN}

\section{Sifat Sensoris Bubur Instan}

Pengujian sifat sensoris merupakan cara-cara pengujian terhadap sifat-sifat bahan pangan dengan menggunakan indera manusia termasuk indera pengelihatan, perasa dan pembau. Dalam penelitian ini pengujian sensoris menggunakan uji kesukaan dengan metode scoring untuk memilih atau menentukan formula terbaik berdasarkan kesukaan panelis terhadap bubur instan berbahan dasar tepung millet putih dan tepung kacang hijau meliputi parameter warna, aroma, rasa, tekstur dan keseluruhan . 


\section{Tabel 1. Sifat Sensoris Bubur Instan Berbasis Tepung Millet Putih dan Tepung}

Kacang Merah

\begin{tabular}{cccccc}
\hline $\begin{array}{c}\text { Formula Bubur } \\
\text { Instan }\end{array}$ & Warna* $^{*}$ & Aroma* $^{*}$ & Rasa $^{*}$ & Tekstur* & Overall $^{*}$ \\
\hline F1 & $3,87^{\mathrm{b}}$ & $3,43^{\mathrm{a}}$ & $2,63^{\mathrm{a}}$ & $3,20^{\mathrm{a}}$ & $3,27^{\mathrm{a}}$ \\
F2 & $3,10^{\mathrm{a}}$ & $3,37^{\mathrm{a}}$ & $2,63^{\mathrm{a}}$ & $3,00^{\mathrm{a}}$ & $2,90^{\mathrm{a}}$ \\
F3 & $3,03^{\mathrm{a}}$ & $3,43^{\mathrm{a}}$ & $2,87^{\mathrm{a}}$ & $2,90^{\mathrm{a}}$ & $2,90^{\mathrm{a}}$
\end{tabular}

Keterangan : Angka yang diikuti huruf yang berbeda pada tiap kolom menunjukkan adanya beda nyata pada taraf signifikansi $\alpha=5 \%$

Hasil uji sensoris menunjukkan bahwa untuk parameter warna, F1 berbeda nyata dengan kedua formulasi yang lain. Sampel F2 dan F3 tidak menunjukkan adanya beda nyata. Dari hasil tersebut dapat diketahui bahwa semakin banyak penggunaan tepung kacang merah pratanak warna bubur yang dihasilkan semakin tidak disukai oleh panelis.

Hal ini disebabkan tingginya protein pada tepung kacang merah dapat menimbulkan reaksi maillard yang menimbulkan warna gelap saat proses pemasakan. Reaksi maillard adalah terbentuknya warna gelap pada suatu bahan yang terjadi karena adanya reaksi antara gula reduksi dan protein pada saat pemanasan lebih dari $35^{\circ} \mathrm{C}$.

Untuk parameter aroma, variasi penggunaan tepung millet putih dan tepung kacang merah tidak memberikan pengaruh yang nyata terhadap aroma bubur instan yang dihasilkan baik pada sampel bubur instan F1, F2 dan F3. Hal ini mungkin disebabkan karena perbandingan antara penggunaan tepung millet putih dan tepung kacang merah tidak begitu besar perbedaannya. Aroma bubur instan sedikit apek dan agak langu, yang disebabkan oleh penggunaan tepung millet putih dan tepung kacang merah. Zat anti gizi yang terdapat pada millet adalah asam fitat, goitrogen, dan asam oksalat.
Komponen goitrogen pada millet diduga merupakan komponen flavonoid, diidentifikasi sebagai penyebab off-odor pada tepung millet (Taylor and Emmambux, 2008 dalam Savitri, 2014). Bau agak langu disebabkan karena kacang merah mengandung enzim lipoksigenase yang menghasilkan beany flavor atau bau langu (Sinaga, 2002).

Untuk parameter rasa, tekstur, dan overall, variasi penggunaan tepung millet putih dan tepung kacang hijau tidak memberikan pengaruh yang nyata. Hasil yang tidak berbeda nyata antara ketiga formula tersebut terjadi karena perbandingan jumlah tepung millet dan tepung kacang hijau yang tidak terlalu besar sehingga tidak mempengaruhi ketiga parameter tersebut.

Berdasarkan hasil pengujian sifat sensoris pada kelima parameter yaitu warna, aroma, rasa, tekstur dan keseluruhan (overall) maka dapat diketahui tingkat kesukaan panelis terhadap masing-masing formula bubur instan pada setiap parameter sehingga dihasilkan formula terpilih. Penentuan formula terpilih tersebut dilakukan dengan mengambil nilai rata-rata terbaik pada masing-masing parameter berdasarkan uji sensoris. Dari hasil pengujian sifat sensoris, dapat disimpulkan bahwa F1 merupakan formula bubur instan terpilih (Tabel 2).

\section{Tabel 2. Pemilihan Formula Bubur Instan Terbaik Berdasarkan Sifat Sensoris}

\begin{tabular}{cccccc}
\hline $\begin{array}{c}\text { Formula Bubur } \\
\text { Instan }\end{array}$ & Warna* & Aroma* & Rasa* & Tekstur* & Overall* \\
\hline F1 & $3,87^{\mathrm{b}}$ & $3,43^{\mathrm{a}}$ & $2,63^{\mathrm{a}}$ & $3,20^{\mathrm{a}}$ & $3,27^{\mathrm{a}}$ \\
F2 & $3,10^{\mathrm{a}}$ & $3,37^{\mathrm{a}}$ & $2,63^{\mathrm{a}}$ & $3,00^{\mathrm{a}}$ & $2,90^{\mathrm{a}}$ \\
F3 & $3,03^{\mathrm{a}}$ & $3,43^{\mathrm{a}}$ & $2,87^{\mathrm{a}}$ & $2,90^{\mathrm{a}}$ & $2,90^{\mathrm{a}}$ \\
\hline
\end{tabular}

Keterangan : Angka yang diikuti huruf yang berbeda pada tiap kolom menunjukkan adanya beda nyata pada taraf signifikansi $\alpha=5 \%$ 
Sifat Kimia dan Total Kalori Bubur Instan

Analisis kimia dilakukan untuk mengetahui kandungan kimia bahan dan mengetahui adanya perubahan komposisi kimia selama proses pengolahan. Formula yang terpilih berdasarkan sifat sensoris dianalisis kimia untuk mengetahui kandungan gizi bubur instan berbasis tepung millet putih dan tepung kacang merah. Analisis kimia pada sampel bubur instan berbasis tepung millet putih dan tepung kacang merah meliputi uji kadar air, uji kadar abu, uji kadar lemak, uji kadar protein, dan kadar karbohidrat. Selain analisis kimia, juga ditentukan total kalori dari bubur instan. Analisis kimia dan total kalori yang dihasilkan kemudian dibandingkan dengan bubur instan komersial. Hasil analisis kimia dan total kalori bubur instan berbasis tepung millet putih dan tepung kacang merah dan bubur instan komersial dapat dilihat pada Tabel 3.

\section{Tabel 3. Hasil Analisis Kimia dan Total Kalori Bubur Instan Berbasis Tepung Millet Putih dan Tepung Kacang Merah dan Bubur Instan Komersial}

\begin{tabular}{lrc}
\hline \multicolumn{1}{c}{ Analisis } & $\begin{array}{r}\text { Bubur } \\
\text { Instan }\end{array}$ & $\begin{array}{c}\text { Bubur } \\
\text { Instan } \\
\text { Komersial }\end{array}$ \\
\hline Kadar Air (\%db) & $5,46^{\mathrm{a}}$ & $6,16^{\mathrm{a}}$ \\
Kadar Abu (\%db) & $4,12^{\mathrm{b}}$ & $0,21^{\mathrm{a}}$ \\
Kadar Lemak (\%db) & $5,42^{\mathrm{a}}$ & $6,66^{\mathrm{b}}$ \\
Kadar Protein (\%db) & $10,73^{\mathrm{b}}$ & $4,44^{\mathrm{a}}$ \\
Kadar Karbohidrat (\%db) & $74,17^{\mathrm{a}}$ & $75,48^{\mathrm{b}}$ \\
Total Kalori (kkal) & $205,38^{\mathrm{a}}$ & $170^{\mathrm{a}}$ \\
\hline
\end{tabular}

Keterangan: Notasi huruf yang berbeda menunjukkan beda nyata pada taraf signifikansi 5\%

Hasil analisis kadar air bubur instan berbasis tepung millet putih dan tepung kacang merah sebesar 5,18\%. Setelah dilakukan analisis statistik dengan menggunakan uji T-Test pada tingkat kepercayaan $95 \%$, nilai kadar air bubur instan tidak berbeda nyata $(\alpha>0,05)$ dengan bubur instan komersial.

Kadar abu pada sampel bubur instan berbasis tepung millet putih dan tepung kacang merah sebesar $4,12 \%$. Setelah dilakukan analisis statistik dengan menggunakan uji T-Test pada tingkat kepercayaan 95\%, nilai kadar abu bubur instan berbeda nyata $(\alpha<0,05)$ dengan bubur instan komersial. Kandungan mineral pada bubur instan berbasis tepung millet putih dan tepung kacang merah lebih tinggi dibanding dengan kandungan mineral pada bubur instan komersial. Kandungan mineral bubur instan ini bersumber dari bahan penyusunnya, yaitu tepung millet putih yang memiliki kandungan mineral sebesar $1,16 \%$ dan tepung kacang merah yang memiliki kandungan mineral sebesar 3,82\%.

Dari Tabel 3 dapat diketahui bahwa besarnya kadar lemak pada sampel bubur instan berbasis tepung millet putih dan tepung kacang merah adalah 5,42\%. Setelah dilakukan analisis statistik dengan menggunakan uji T-Test pada tingkat kepercayaan 95\%, nilai kadar lemak bubur instan berbeda nyata $(\alpha<0,05)$ dengan bubur instan komersial. Kandungan lemak pada bubur instan lebih rendah jika dibanding dengan kandungan lemak pada bubur instan komersial. Kandungan lemak pada bubur instan komersial tinggi karena di dalam bubur instan komersial terdapat minyak bumbu. Selain itu, ada kerupuk yang menyumbang nilai kandungan lemak dari bubur instan komersial itu sendiri.

Kadar protein pada sampel bubur instan berbasis tepung millet putih dan tepung kacang merah sebesar $10,73 \%$. Setelah dilakukan analisis statistik dengan menggunakan uji T-Test pada tingkat kepercayaan $95 \%$, nilai kadar protein bubur instan berbeda nyata $(\alpha<0,05)$ dengan bubur instan komersial. Kadar protein bubur instan berbasis tepung millet putih dan tepung kacang merah lebih tinggi jika dibandingkan dengan bubur instan komersial. Hal ini disebabkan karena salah satu bahan baku bubur instan adalah tepung kacang merah. Berdasarkan data dari Direktorat Gizi, Depkes (1992), kandungan protein pada kacang merah sebesar $23,1 \%$. Tepung kacang merah yang digunakan dalam pembuatan bubur instan berbasis tepung millet putih dan tepung kacang merah ini adalah tepung 
kacang merah pratanak yang memiliki kandungan protein sebesar 19,16\%.

Dari Tabel 3 dapat diketahui bahwa besarnya kadar karbohidrat pada sampel bubur instan berbasis tepung millet putih dan tepung kacang merah adalah $74,17 \%$. Setelah dilakukan analisis statistik dengan menggunakan uji T-Test pada tingkat kepercayaan 95\%, nilai kadar karbohidrat bubur instan berbeda nyata $(\alpha<0,05)$ dengan bubur instan komersial. Kadar karbohidrat pada bubur instan komersial lebih tinggi jika dibandingkan dengan kadar karbohidrat bubur instan berbasis tepung millet putih dan tepung kacang merah. Hal ini disebabkan tepung millet putih dan tepung kacang merah sebagai bahan baku yang digunakan dalam pembuatan bubur instan mengandung karbohidrat yang lebih kecil yaitu tepung millet putih mengandung karbohidrat sebesar $78,46 \%$ dan tepung kacang merah mengandung karbohidrat sebesar $64,47 \%$. Sedangkan tepung beras sebagai bahan baku pembuatan bubur instan komersial mengandung karbohidrat sebesar $91,51 \%$ (Koswara, 2009).

Total kalori pada sampel bubur instan berbasis tepung millet putih dan tepung kacang merah adalah 205,38 kkal. Setelah dilakukan analisis statistik dengan menggunakan uji T-Test pada tingkat kepercayaan $95 \%$, nilai kalori bubur instan tidak berbeda nyata $(\alpha>0,05)$ dengan bubur instan komersial. Menurut Muchtadi (2009), energi yang terkandung dalam makanan tergantung dari jumlah zat gizi yang terkandung dalam makanan. Dalam pembuatan bubur instan ini, digunakan bahan baku berupa tepung millet putih dan tepung kacang merah, serta bahan tambahan berupa susu bubuk full cream, gula halus, dan garam. Masing-masing komponen penyusun dalam pembuatan bubur instan ini menyumbang energi dalam produk bubur instan berbasis tepung millet putih dan tepung kacang merah, seperti tepung millet putih yang memiliki kadar karbohidrat yang tinggi, tepung kacang merah yang memilki kadar protein yang tinggi, susu bubuk full cream yang memiliki kadar lemak yang tinggi, sehingga dihasilkan kalori yang tinggi pula.

\section{KESIMPULAN}

Formula terpilih bubur instan berdasarkan sifat sensoris adalah $39.59 \%$ tepung millet putih, $31.25 \%$ tepung kacang merah, $17.71 \%$ susu bubuk, $10.41 \%$ gula halus, dan $1.04 \%$ garam. Sedangkan komposisi kimia bubur instan formula terpilih kadar air $5.46 \%$, kadar abu 4,12\%, kadar lemak 5,42 \%, kadar protein $10.73 \%$, dan kadar karbohidrat $74.27 \%$. Nilai kalori setiap 48 gram adalah 205.38 kkal. Kadar abu dan kadar protein bubur instan berbasis tepung millet putih dan tepung kacang merah pratanak lebih tinggi jika dibandingkan dengan bubur komersial.

\section{DAFTAR PUSTAKA}

Almatsier, S. 2001. Prinsip Dasar Ilmu Gizi. Gramedia Pustaka Utama. Jakarta.

Anandito,R. B. K, Dian Rachmawanti, dan Esti Widowati. 2010. Bubur Bayi Kaya Nutrisi Alami Berbahan Baku Tepung Millet Kuning dan Tepung Daun Kelor, Laporan Penelitian DIPA BLU, Universitas Sebelas Maret, Surakarta.

AOAC. 1995. Official Methods of Analysis . Association of Official Analytical Chemists, Washinton DC.

Ardianditto, D., R. Baskara Katri Anandito, Nur Her Riyadi Parnanto, dan Dian Rachmawanti. 2013. Kajian Karakteristik Bubur Bayi Instan Berbahan Dasar Tepung Millet dan Tepung Beras Merah dengan Flavor Alami Pisang Ambon sebagai Makanan Pendamping ASI, Jurnal Teknosain Pangan vol.2 no.1.

Arifianti, A., R. Baskara Katri Anandito, Dian Rachmawanti, dan Nur Her Riyadi Parnanto. 2012. Karakterisasi Bubur 
Bayi Instan Berbahan Baku Tepung Millet dan Tepung Beras Hitam dengan Flavor Alami Pisang Ambon, Jurnal Teknosain Pangan vol. 1 no. 1.

Arinanti, M. 2005. Aktivitas Antioksidan Komponen Fenolik dan Asam Fitat pada Berbagai Jenis Kacang. Tesis, Program Studi Ilmu dan Teknologi Pangan, Sekolah Pascasarjana Universitas Gadjah Mada, Yogyakarta.

Faesal. 2013. Peningkatan Peran Penelitian Tanaman Serealia Menuju Pangan Mandiri. Seminar Nasional Serealia. ISBN 978-979-8940-37-8, Hal.199. Balai Penelitian Tanaman Serealia.

Husna, E. A, Dian Rachmawanti, Kawiji, dan R. Baskara Katri Anandito. 2012. Karakterisasi Bubur Bayi Instan Berbahan Dasar Tepung Millet dan Tepung Kacang Hijau dengan Flavor Alami Pisang Ambon, Jurnal Teknosain Pangan vol. 1 no. 1.

Koswara. 2009. Teknologi Pengolahan Beras. ebookpangan.com. Diakses pada 25 Juni 2014 Pukul 15.00 WIB.

Marsono, Y., Z. Noor. dan F. Rahmawati. 2003. Pengaruh Diet Kacang Merah terhadap Kadar Gula Darah Tikus Diabetik Induksi Alloxan. Jurnal Teknologi dan Industri Pangan, Vol.XIV, No.1, hal.1.

Muchtadi, Deddy. 2009. Karbohidrat Pangan dan Kesehatan. Alfabeta. Bandung.

Mulyaningsih, Yeni dan J. Rosida. 2002. Membandingkan Hasil Analisa Energi Total menggunakan Bom Kalorimeter dengan Hasil Analisis Proksimat. Jurnal Teknis Fungsional Non Penelitian.
Pramesta, L.D., Dian Rachmawanti, Kawiji, dan R. Baskara Katri Anandito. 2012. Karakterisasi Bubur Bayi Instan Berbahan Dasar Tepung Millet dan Tepung Kacang Merah dengan Flavor Alami Pisang Ambon, Jurnal Teknosain Pangan vol. 1 no. 1.

Rachmawati, D; R. B. K. Anandito; dan Lia Umi K. 2010. Pemenfaatan Millet Kuning sebagai Subtitusi Pembuatan mie Kering, Laporan Penelitian Pemula, Diknas Jateng.

Rehman., Zia-ur., Salariya, A.M., dan Zafar, S.I. 2000. Effect of Processing in Available Carbohydrate Content and Starch Digestibility of Kidney Bean (Phaseolus vulgaris L.). Food Chemistry 73: 351-355.

Savitri, Endang. 2014. Formulasi Pangan Darurat Berbentuk Food Bars Berbasis Tepung Millet Putih (Panicum miliceum L.) dan Tepung Kacang Merah (Phaseolus vulgaris L.) dengan Penambahan Gliserol sebagai Humektan. Skripsi. Ilmu dan Teknologi Pangan. Fakultas Pertanian. Universitas Sebelas Maret. Surakarta.

Setyaningsih, Dwi., Anton Apriyantono dan Maya Puspita Sari. 2010. Analisis Sensoris. Institut Pertanian Bogor Press. Bogor.

Sinaga. 2002. Teknologi Hasil Hortikultura. Balitsa. Lembang. Bandung

Slamet, Agus. 2011. Fortifikasi Tepung Wortel dalam Pembuatan Bubur Instan untuk Peningkatan Provitamin A. Agrointek, Vol.5, No.1 